\title{
SOSIALISASI TEMAN BISNIS CATATAN KEUANGAN
}

\author{
Wahyu Nurul Hidayati ${ }^{1}$, Aris Sanulika ${ }^{2}$,Endang Ruhiyat ${ }^{3}$, Holiawati $^{4}$, Hari Stiawan ${ }^{5}$ \\ S1 Akuntansi, Fakultas Ekonomi, UniversitasPamulang \\ ${ }^{1}$ Wahyu.nuhi@gmail.com, ${ }^{2}$ dosen01236@unpam.ac.id, ${ }^{3}$ hari.stiawan33@gmail.com, \\ ${ }^{4}$ holienroe@yahoo.com, ${ }^{5}$ dosen00011@unpam.ac.id \\ ${ }^{* 1}$ Wahyu.nuhi@gmail.com
}

\begin{abstract}
Abstrak
Pengabdian kepada masyarakat dapat diartikan sebagai respon akademik masyarakat kampusatas kebutuhan, tantangan, atau persoalan yang dihadapi oleh masyarakat, baik secara langsung maupun tidak langsung. Tujuan umum dari kegiatan pengabdian kepada masyarakat ini adalah membantu pembudi daya ikan di desa Jampang, Bogor dalam mengatasi persoalanpersoalan pencatatan laporan keuangan. Adapun bentuk kegiatan dalam pelaksanaan pengabdian kepada masyarakat dengan tema akuntansi keuangan. Dengan para pengajar dan narasumber yang dilibatkan adalah para Dosen Program Studi Akuntansi dari Universitas Pamulang. Hasil Pelaksanaan PKM yang dilakukan tanggal 20, 21 dan 22 September 2019 adalah menambah ilmu mereka di bidang akuntansi, terutang tentang pencatatan keuangan, para peserta kelompok ikan hias di desa Jampang sangat antusias dengan materi yang mereka dapatkan dari dosen-dosen akuntansi Universitas Pamulang, Para peserta dapat langsung mempraktekan pembukuan secara manual, Respon para peserta sangat baik dan senang karena sangat terbantu dalam pembelajaran tentang pencatatan keuangan. Pentingnya pengelolaan aspek keuangan usaha membuat parakelompok pembudidaya sadar bahwa pendapatan harus di putar agar usaha terusmaju. Saran yang disampaikan adalah kegiatan PKM kedepannya agar digalakan dan dibuat semenarik mungkin agar dapat menjaring lebih banyak lagi peserta kelompok Ikan Hias di desa Jampang, perluasan jangkauan cakupan wilayah materi bisa lebih diperluas sehingga peserta dapat memperoleh wawasan lebih banyak.
\end{abstract}

Kata kunci : Pembukuan Manual; Berwirausaha.

\begin{abstract}
Community service can be interpreted as an academic response from the campus community to the needs, challenges, or problems faced by the community, both directly and indirectly. The general objective of community service activities is to assist fish farmers in the Jampang area, Bogor in overcoming the problems of recording financial statements. The form of activities in the implementation of community service with the theme of financial accounting. The instructors and resource persons involved were Accounting Study Program Lecturers from Pamulang University. The results of the PKM Implementation conducted on 20.21 and 22 September 2019 were adding to their knowledge in the field of accounting, owing to financial records, the ornamental fish group participants in the village of Jampang were very enthusiastic about the material they got from accounting lecturers at the University of Pamulang, participants can directly practice bookkeeping manually, the response of the participants is very good and happy because it is very helpful in learning about financial records. The importance of managing the financial aspects of the business made the farmers' groups aware that income had to be rotated to keep the business going. The suggestion given is that the PKM activities in the future should be encouraged and made as attractive as possible so that they can capture more Ornamental Fish group participants in the village of Jampang, expanding the scope of coverage of the material area can be expanded so that participants can gain more insight.
\end{abstract}

Keywords: Bookkeeping Manual, Entrepreneurship, 


\section{PENDAHULUAN}

Pengabdian kepada masyarakat dapat diartikan sebagai respon akademik masyarakat kampus atas kebutuhan, tantangan, atau persoalan yang dihadapi oleh masyarakat, baik secara langsung maupun tidak langsung.

Berbekal kompetensi keilmuan yang dimiliki, kegiatan ini merupakan aktualisasi dari tanggung jawab dan kepedulian sosial warga kampus kepada masyarakat luas, yang meliputi usahausaha nyata untuk meningkatkan kualitas sumber daya manusia melalui perluasan wawasan dan pengetahuan, serta peningkatan keterampilan hidup. Terkandung di dalamnya partisipasi aktif, kreatif, dan inovatif warga kampus dalam berbagai bentuk community development yang bersifat transformatif, sehingga masyarakat mampu mencapai kehidupan yang lebih baik (mandiri dan bermartabat).

Dari observasi lapangan terdapat permasalahan bahwa kelompok pembudidaya ikan masih bingung dan tidak rapih dalam hal catat mencatat kegiatan ekonominya terutama dalam system akuntansi berapa penjualan dan keuntungan setiap bulan yang mereka hasilkan mereka masih bingung dan tidak ada pencatatan sehingga mereka tidak bisa membuat strategi manajemen keuangan yang bagus.
Adapun tujuan dari pengabdian kepada masyarakat ini adalah untuk membantu pembudidaya ikan di daerah Jampang, Bogor dalam mengatasi persoalanpersoalan pencatatan laporan keuangan.

\section{METODE}

Kegiatan pengabdian kepada masyarakat ini mengusung tema "Sosialisasi Teman Bisnis Catatan Keuangan“ dilaksanakan di Aula Setu

Desa Jampang, Bogor, Jawa Barat terletak di tepian sebuah danau yang terbentuk secara alami, bernama Setu Cilala. Setu seluas 21 hektar ini menjadi lahan usaha warga setempat yang menjadikannya sebagai tempat budidaya ikan. Jenis ikan hias yang menjadi primadona desa Jampang adalah ikan mas Koki, dan ikan Gurame untuk jenis ikan konsumsinya. Hampir sebagian besar warga Desa Jampang melakukan usaha budidaya ikan hias dengan memanfaatkan $25 \%$ dari luas setu. Di desa ini terdapat sekitar 60 pembudidaya dengan jenis usaha (pengolah hasil ikan, budidaya ikan hias dan ikan konsumsi).

Kegiatan Pengabdian Kepada Masyarakat dilakukan melalui penyuluhan dan presentasi materi tentang sosialisasi teman bisnis catatan keuangan yang di paparkan oleh Ibu Aris Sanulika. S.E., M.Ak., materi yang disampaikan oleh narasumber diawali dengan penjelasan 
tentang akuntansi teutama tentang pencatatan keuangan, memberikan wawasan tentang mengelola keuangan dengan baik dan benar agar keuangan kelompok tani ikan hias dapat terkoordinir dengan baik, serta memberikan pemahaman akan motivasi dan semangat kepada peserta untuk memperbaiki kondisi keuangan kelompok tani ikan hias agar terarah.

Kegiatan lebih rinci tertuang dalam dibawah ini:

Tabel 1. Susunan acara kegiatan

\begin{tabular}{|c|c|c|c|c|}
\hline No. & Tanggal & Waktu & Acara & Pelaksana \\
\hline 1. & $20-9-19$ & $\begin{array}{l}14.00- \\
16.00\end{array}$ & $\begin{array}{l}\text { Survei } \\
\text { lapangan } \\
\text { mencari tahu } \\
\text { apa saja yang } \\
\text { dibutukan } \\
\text { dengan oleh } \\
\text { kelompok } \\
\text { ikan }\end{array}$ & $\begin{array}{l}\text { Wahyu Nurul } \\
\text { Hidayati, S.E., Ak., } \\
\text { M.Ak } \\
\text { Aris Sanulika, SE, } \\
\text { M.Ak }\end{array}$ \\
\hline 2. & $21-9-19$ & $\begin{array}{l}12.00- \\
17.00\end{array}$ & $\begin{array}{l}\text { Menyiapkan } \\
\text { materi } \\
\text { pelaksanaan, } \\
\text { sarana dan } \\
\text { prasarana } \\
\text { pelaksanaan } \\
\text { kegiatan }\end{array}$ & $\begin{array}{l}\text { Wahyu Nurul } \\
\text { Hidayati, S.E., Ak., } \\
\text { M.Ak } \\
\text { H. Endang Ruhiyat, } \\
\text { S.E., } \\
\text { M.M.,CSRA,CMA } \\
\text { Dr. Hj. Holiawati, } \\
\text { S.E., M.Si, CSRS, } \\
\text { CSRA } \\
\text { Hari Setiawan, S.E., } \\
\text { M.Ak. } \\
\text { Aris Sanulika, SE, } \\
\text { M.Ak }\end{array}$ \\
\hline 3. & $22-9-19$ & $\begin{array}{l}09.00- \\
09.15\end{array}$ & Pembukaan & $\begin{array}{l}\text { Mahasiswa } \\
\text { Universitas } \\
\text { Pamulang } \\
\end{array}$ \\
\hline 4. & & $\begin{array}{l}09.15- \\
10.00\end{array}$ & $\begin{array}{l}\text { Sambutan } \\
\text { dan Doa }\end{array}$ & $\begin{array}{l}\text { Wahyu Nurul } \\
\text { Hidayati,S.E., Ak., } \\
\text { M.Ak }\end{array}$ \\
\hline 5. & & $\begin{array}{l}10.00- \\
10.45\end{array}$ & $\begin{array}{l}\text { Sambutan } \\
\text { Ketua } \\
\text { Kelompok } \\
\text { Ikan Hias }\end{array}$ & Bapak Kaman \\
\hline
\end{tabular}

\begin{tabular}{|c|c|c|c|c|}
\hline No. & Tanggal & Waktu & Acara & Pelaksana \\
\hline 6. & & $\begin{array}{l}10.45- \\
11.30\end{array}$ & Seminar & $\begin{array}{l}\text { Aris Sanulika, SE, } \\
\text { M.Ak }\end{array}$ \\
\hline 7. & & $\begin{array}{l}11.30- \\
12.00\end{array}$ & $\begin{array}{l}\text { Sesi } \\
\text { Tanya Jawab }\end{array}$ & $\begin{array}{l}\text { Aris Sanulika, SE, } \\
\text { M.Ak }\end{array}$ \\
\hline 8. & & $\begin{array}{l}12.00- \\
13.00\end{array}$ & Isoma & \\
\hline 9. & & $\begin{array}{l}13.00- \\
13.15\end{array}$ & $\begin{array}{l}\text { Pemberian } \\
\text { Kenang- } \\
\text { Kenangan }\end{array}$ & $\begin{array}{l}\text { Wahyu Nurul } \\
\text { Hidayati, S.E., Ak., } \\
\text { M.Ak/ Bapak } \\
\text { Kaman }\end{array}$ \\
\hline 10. & & $\begin{array}{l}13.15- \\
13.30\end{array}$ & $\begin{array}{l}\text { Kesimpulan } \\
\text { dan Penutup }\end{array}$ & $\begin{array}{l}\text { Mahasiswa } \\
\text { Universitas } \\
\text { Pamulang }\end{array}$ \\
\hline 11. & & $\begin{array}{l}13.30- \\
14.00\end{array}$ & $\begin{array}{l}\text { Foto } \\
\text { Bersama }\end{array}$ & \\
\hline
\end{tabular}

\section{HASIL DAN PEMBAHASAN}

Kegiatan pengabdian kepada masyarakat ini dilaksanakan di desa Jampang Kab.Bogor Jawa Barat. Kegiatan ini diikuti oleh beberapa kelompok Tani Ikan hias pada tanggal 20,21,22 September 2019 pada pukul 09.00 sampai 12.00 WIB. Secara umum kegiatan ini berjalan dengan lancar dan antusiasme yang tinggi para petani kelompok ikan untuk mengikuti kegiatan tersebut karena mereka ingin mengetahui bagaimana cara mengatur keuangan dan pencatatan keuangan dengan baik dan benar dalam usaha ikan hias agar lebih terlihat keluar masuknya perputaran pendapatan usaha ikan hias tersebut.

Antusias para kelompok tani dalam sosialisasi dapat dilihat pada gambar berikut ini: 


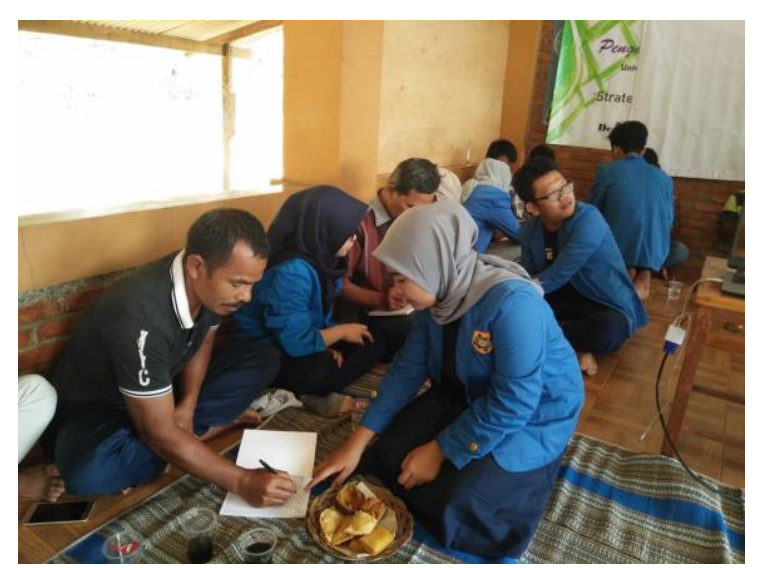

Gambar 1. Antusias peserta dalam membuat pencatatan keuangan

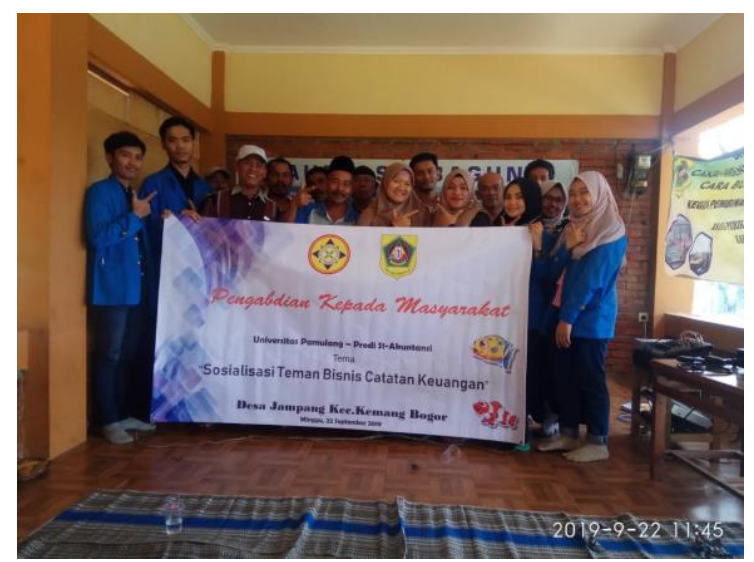

Gambar 2.Antusias peserta kelompok tani ikan hias

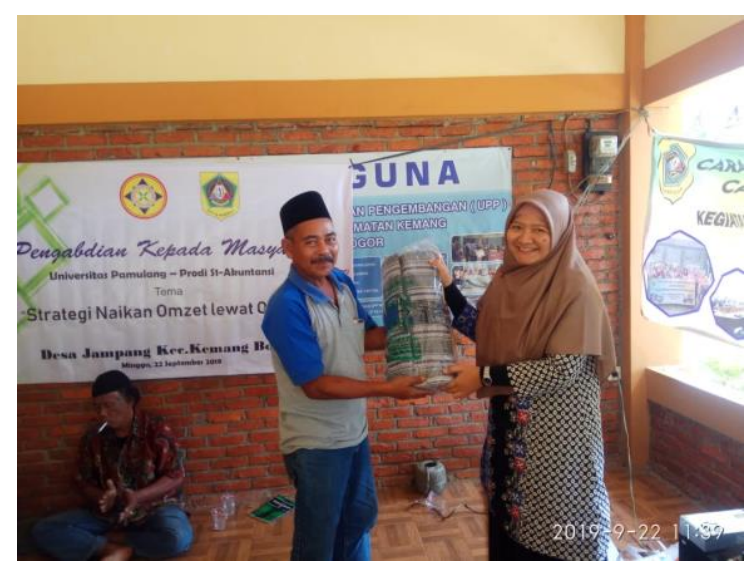

Gambar 3.Penyerahan Cideramata untuk para kelompok petani ikan hias

Materi yang disampaikan dalam kegiatan pengabdian kepada masyarakat ini adalah memberikan wawasan tentang mengelola keuangan dengan baik melalui pencatatan keuangan ,memberikan pemahaman akan manfaat pencatatan keuangan untuk mengatur keuangan usaha ikan hias. Pemateri memberikan motivasi dan semangat kepada peserta untuk memperbaiki pelaporan kondisi keuangan usaha ikan hias melalui pemanfaatan pencatatan laporan keuangan secara manual.

Dengan diberikan pemahaman di atas para kelompok petani ikan hias lebih tahu jelas manfaat dari pencatatan keuangan. Dalam sebuah forum tanya jawab diungkapkan bahwa setelah mereka mendengarkan penjelasan dari narasumber, para peserta kelompok tani ikan hias sangat termotivasi untuk terus melakukan pencatatan pembukuan secara manual, seeiring berjalanakan dilaksanakan dengan pencatatan pembukuan secara online. Materi yang disampaikan pada saat sosialisasi tentang pentingnya pencatatan laporan keuangan dengan tema" Sosialisasi teman bisnis catatan keuangan" yaitu:

1. Mensosialisasikan manajemen keuangan yang dirasa masih membingungkan

2. Membantu untuk memberikan kemudahan dalam tata cara pembukuan kepada kelompok tani ikan hias di desa Jampang 
3. Membantu memberikan informasi dalam penyusunan laporan keuangan agar Kelompok Ikan Hias di desa Jampang dapat melihat perkembangan pergerakan arus kasnya serta untung dan ruginya

4. Memberikan motivasi pentingnya pencatatan dalam laporan keuangan setiap usahanya

Setelah dilakukan sosialisasi pencatatan keuangan untuk kelompok tani ikan hias dilakukan sesi Tanya jawab mengenai pemanfaatan catatan laporan keuangan diselingi dengan kegiatan games. Setelah dilakukan pemaparan materi oleh narasumber dan sesi tanya jawab mengenai catatan keuangan kami para narasumber juga melakukan wawancara langsung kepada para peserta untuk menanyakan seberapa tertariknya mereka terhadap kegiatan ini dan mereka memberikan jawaban bahwa sangat senang sekali, dan kalau bisa terus diadakan kegiatan sosialisasi sebagai bentuk kelanjutan kerjasama yang baik antara Universitas Pamulang dengan kelompok tani ikan hias di desa Jampang.

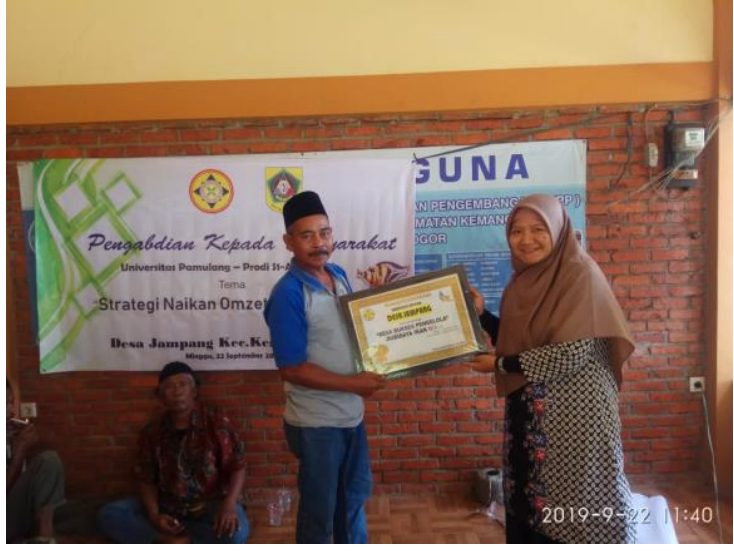

Gambar 4.Pemberian Piagam penghargaan kepada Ketua Kelompok Tani Ikan Hias

Kegiatan pengabdian ini dinilai sangat bermanfaat dengan kondisi para peserta kelompok tani ikan hias desa Jampang yang notabenenya masih belum dan awam dalam pencatatan keuangan secara rapi.

Peserta masih sangat membutuhkan terkait informasi mengenai pencatatan tersebut agar terlihat pengeluaran dan pencapatan secara baik. Pada pelaksaaan kegiatan ini tim dosen tidak mengalami hambatan yang berarti, karena dari awal sudah melakukan survey kepada ketua kelompok ikan tani dan menyambut baik dengan proposal kami ketika proposal kami diajukan. Karena Desa Jampang ini merupakan Desa Binaan Universitas Pamulang .

\section{KESIMPULAN}

Setiap kegiatan ekonomi tentunya harus diiringi dengan pembukuan finansial yang memadai agar pengeluaran dan pemasukan usaha dapat dimonitor secara 
akurat. Selain itu, pembukuan yang benar juga akan bermanfaat dalam membantu mengambil keputusan dan pertanggungjawaban bisnis. Ketidaksiapan kelompok pembudidaya ikan yang secara tiba-tiba atau signifikan mengalami kenaikan omzet dan sekaligus kenaikan laba bisa menyebabkan pembudidaya ikan menjadi konsumtif luar biasa. Merasa penghasilannya berubah tinggi, maka mereka lupa bahwasannya uang itu harus diputar sepersekian persennya ke dalam perputaran usaha. Bahwa tidak serta merta keuntungan itu bisa dinikmati semua dengan belanja kebutuhan sekunder dan tersier. Apabila ada penurunan omzet mereka tidak siap dan merasa merugi besar karena tidak adanya kesiapan mengelola aspek keuangan usaha.

Diharapkan setelah adanya pembelajaran pemahaman tentang catatan keuangan kepada Kelompok Ikan Hias di desa Jampang dapat dengan mudah untuk menerapkan pencatatan keuangan .

\section{Saran}

Pelaksanaan kegiatan PKM ini diharapkan tetap dilakukan secara rutin untuk membantu para kelompok tani ikan desa Jampang agar memperoleh pencatatan yang baik dalam setiap usaha ikan hiasnya. Beberapa saran yang disampaikan adalah sebagai berikut:
1. Kegiatan serupa ke depannya agar digalakkan dan dibuat semenarik mungkin agar dapat menjaring lebih banyak lagi peserta Kelompok Ikan Hias di desa Jampang.

2. Perluasan jangkauan cakupan wilayah serta materi bisa lebih diperluas lagi sehingga para peserta diharapkan dapat memperoleh wawasan yang lebih banyak.

\section{DAFTAR PUSTAKA}
https://aptika.kominfo.go.id/2018/11/petan i-dan-nelayan-go-online/ http://www.radarbogor.id/2018/03/29/foku s-garap-kampung-wisata/ 